\title{
Da reflexão sobre pós-verdade e fake news à análise sobre a revista piauí e a agência $L$ upa
}

\section{Otávio Daros}

Doutorando em Comunicação Social pela Pontifícia Universidade Católica do Rio Grande do Sul, em cooperação com a Universidade de Bremen. Fellow do Laboratório de História da

Comunicação e Mudança da Mídia, na Universidade de Bremen.

E-mail: otavio.daros@ gmail.com
SANTOS, Kassia Nobre dos. Em busca da credibilidade perdida: a rede de investigação jornalística na era das fake news. Belo Horizonte: Editora Letramento, 2019. 164 páginas.

Grandes nomes das áreas de jornalismo e comunicação têm se ocupado recentemente da reflexão sobre fake news e pós-verdade, como Eugênio Bucci (2019) e Lucia Santaella (2018). Lançado em 2019, o livro de Kassia Nobre dos Santos, apresentado como tese no Programa de Pós-Graduação em Comunicação e Semiótica da Pontifícia Universidade Católica de São Paulo, pretende contribuir para a discussão teórica sobre o tema, ao mesmo tempo que oferece pesquisa empírica, com a análise de dois casos. Em busca da credibilidade perdida: a rede de investigação jornalística na era das fake news analisa os processos de produção de reportagens na revista piauí, bem como os processos de checagem de informações na agência Lupa. São projetos autônomos, embora mantenham parceria entre si e com o jornal Folha de S. Paulo e com o portal UOL. Sua tese é que "o jornalismo está em crise, mas devido a essa instabilidade, pilares fundamentais da profissão - a apuração aprofundada e a checagem - foram resgatados e valorizados a partir da criação de novos modelos de trabalho e, consequentemente, novos modelos de negócio" (SANTOS, 2018, p. 10).

O livro está dividido em seis capítulos, incluindo considerações finais. $\mathrm{Na}$ introdução (p. 11-18, 2019), a autora lança breve contextualização traçando, de modo tímido, a relação entre a crise financeira dos jornais e das revistas e a crise de credibilidade enfrentada pelo próprio jornalismo. Depois, ela apresenta sua linha de trabalho - o estudo sobre os processos de produção do jornalismo - , informando que tomará como referência teórico-metodológica o trabalho de sua orientadora Cecília Salles (2007), por sua vez, interessada na reflexão dos processos criativos. No que tange especificamente à metodologia, sua análise trabalha com "documentos de processos", isto é, o conjunto de "registros materiais do processo criador", como depoimentos de jornalistas (SALLES apud SANTOS, 2008, p. 13).

No segundo capítulo, Santos revisa os autores que trataram do surgimento dos jornais, no contexto amplo global, a produção da reportagem, no contexto específico brasileiro, e as transformações que ocorreram neste cenário após o advento da internet e, consequentemente, dos sites de redes sociais, retornando ao contexto global. Trata-se de uma revisão sem intervenção crítica, dando a entender, por exemplo, que autores como Nelson Werneck Sodré, Muniz Sodré, Nilson Lage, José Marques de Melo, Bernardo Kucinski, Cremilda Medina, Ciro Marcondes e Felipe Pena compartilham todos de visões semelhantes ou complementares sobre 
a evolução da imprensa e do jornalismo. Esta conduta acrítica torna-se prejudicial, pois reduz ou ignora as diferenças entre eles, e força um único diálogo entre suas abordagens teóricas e históricas, que não pretendem ser semelhantes. Uma revisão com intervenção crítica sobre a matéria consistiria, por exemplo, em captar a ideia específica que cada pensador cultivou sobre o jornalismo, assim como analisar os marcos históricos sobre a imprensa com que cada um trabalhou.

Santos passa então para o capítulo dedicado à revisão teórica sobre pós-verdade e fake news (p. 41-60). A autora revisa autores como Christian Dunker, Matthew D'ancona, Eugênio Bucci e Carlos Castilho. De modo positivo, trabalha com referências nacionais e estrangeiras, demonstrando possuir conhecimento sobre a literatura especializada. Contudo, ela repete o mesmo problema visto no capítulo anterior: usa referencial teórico numeroso, sem situar cada autor em seu respectivo contexto acadêmico ou analisar minuciosamente o conceito que cada um está propondo, por exemplo, indicando qual é o avanço ou o retrocesso em jogo. Optando por combinar tais visões, em vez de ajuíza-la, Santos parte para o desenvolvimento de seu argumento ao longo do capítulo. Argumenta que os sites de redes sociais restringiram a atuação até então hegemônica da "mídia como porta-voz da informação". Segundo ela, os chamados fenômenos de pós-verdade e notícias falsas seriam consequências desta nova dinâmica gerada pela internet.

A pesquisa, no sentido empírico, está concentrada no quarto capítulo (p. 61-112) - a principal seção do livro. Valendo-se de depoimentos, a autora buscou compreender a rotina produtiva/criativa de cada repórter da piauí. Em comum, eles informaram que desfrutam de longo tempo para a produção das reportagens. De modo favorável à pesquisa, Santos expôs com detalhe o relato dos profissionais entrevistados. Por outro lado, sua análise não permitiu, por exemplo, mergulhar no jogo de contradições entre os relatos dos profissionais e a prática jornalística, ou explorar a experiência criativa individual com a dinâmica produtiva coletiva, na qual estão inseridos. Ou ainda nas palavras de Salles, trabalhar com "a dialética entre os limites materiais dos documentos e a ausência de limites do processo; conexões entre aquilo que é registrado e tudo o que acontece, porém não é documentado" (SALLES, 2007, p. 17).

O quinto capítulo, voltado à agência Lupa (p. 113-146), não se vale de devida interpretação sobre o material examinado. A autora propõe uma contextualização oportuna sobre as iniciativas de checagem nos Estados Unidos. Sua referência é o trabalho de Lucas Graves, professor da Universidade de Wisconsin-Madison. Porém, não desenvolve análise minuciosa sobre os processos produtivos/criativos dos jornalistas da agência brasileira, o que exigiria, por exemplo, acompanhá-los e analisar seu trabalho no espaço organizacional. Em vez disso, ela trabalha com o depoimento da criadora da agência e com documentos eletrônicos complementares. Ou seja, lida com uma visão particular para dar conta de todo o processo produtivo/criativo de diversos atores. Logo o que a autora oferece é, mais precisamente, uma descrição sobre o modelo de negócio adotado pela agência e sua metodologia de checagem.

Por fim, nas considerações (p. 147-152), Santos reflete sobre o papel do jornalismo numa sociedade democrática. A autora traz à discussão Edgar Morin e Marcia Tiburi para abordar, respectivamente, o pensamento complexo e o autoritarismo brasileiro. Apesar da iniciativa reflexiva, a autora embarca em uma discussão demasiadamente ampla, não favorecendo a reflexão específica sobre seus achados: os jornalistas como produtores de informação/agentes criativos que atuam nestes dois "novos" empreendimentos. Apesar dos percalços apontados, não se pode ignorar seu mérito propositivo, de buscar novas perspectivas para o problema instalado, indicando potencialidades a serem estudadas, em vez de se fechar em discussão apocalíptica, como historicamente se viu em nossa área (ver SERVA, 2001; KUCINSKI, 2004). 


\section{Referências}

BUCCI, Eugênio. Existe democracia sem verdade factual? Barueri: Estação das Letras e Cores, 2019.

KUCINSKI, Bernardo. Jornalismo na era virtual: ensaios sobre o colapso da razão ética. São Paulo: Editora Fundação Perseu Abramo: Editora UNESP, 2005.

SANTAELLA, Lucia. A pós-verdade é verdadeira ou falsa? Barueri: Estação das Letras e Cores Editora, 2018.

SALLES, Cecília Almeida. Gesto inacabado: processo de criação artística. 3 ed. São Paulo: Intermeios, 2007.

SANTOS, Kassia Nobre dos. Em busca da credibilidade perdida: a rede de investigação jornalística na era das fake news. 2018. 134 f. Tese (Doutorado em Comunicação e Semiótica) - Programa de Estudos Pós-Graduados em Comunicação e Semiótica, Pontifícia Universidade Católica de São Paulo, São Paulo, 2018.

SANTOS, Kassia Nobre dos. Em busca da credibilidade perdida: a rede de investigação jornalística na era das fake news. Belo Horizonte: Editora Letramento, 2019.

SERVA, Leão. Jornalismo e desinformação. São Paulo: Editora Senac, 2001. 